\title{
The implementation of small group discussion in teaching writing recount text for the tenth grade students of SMKN 1 Bendo
}

\author{
Intan Dwi Lestari \\ Department of English Teaching, Universitas PGRI Madiun, Indonesia
}

\begin{tabular}{l} 
Article Info \\
\hline Article history: \\
Received January 18, 2019 \\
Revised March 13, 2019 \\
Accepted June 20, 2019 \\
\hline
\end{tabular}

Keywords:

small group discussion; teaching writing;

recount text.

\begin{abstract}
The goals of this research are to describe the implementation, advantages and disadvantages, and the solution of disadvantages in teaching writing Recount text by using Small Group Discussion. The research uses descriptive qualitative research as approach and type of research. The sources of data are social situation, participant or informant, and document. The technique of collecting data uses observation, interview, and documentation. To know the validity of the data, the researcher uses triangulation. The technique of data analysis are data condensation, data display, conclusion and verification. The result of the research are (1) The implementation of Small Group discussion in teaching writing Recount text divided into (a) Pre-activity which covers greeting, praying, checking attendance list and explaining the purpose of the learning, (b) Whilst-activity covers the explanation the stages of the technique, (c) Post-activity include reviewing and making resume of the material, (2) The advantages are easy to implement in the class and can be understood well by the students, effective to teach types of text, increased participation, make student more intimate with their friend, (3) The disadvantages are student need more times to write, they are difficult in translate the word, disability of implementing correct structure makes some of students did not participate, students' motivation of writing is still low, take long time because there are four stages that should be done by the students, (4) The solution of the disadvantages are teacher gives clear and simple explanation about the material, asks students to bring the dictionary, explains the role of each member of group clearly, makes the activity into simple one, gives additional time, student aware to other students, and teacher gives a bit of joke or humour and motivation in the process of learning. Based on the result, the conclusion of this research are suitable with the lesson plan, observation, and teaching process in the class. The suggestions are presented for teacher should have variety of strategy in teaching writing, students are suggested to increase their vocabulary, and other researcher are suggested to fulfil the need of the knowledge from other point of view.
\end{abstract}

Copyright $(0) 2019$ Department of English Teaching. All rights reserved.

\section{Corresponding Author:}

Intan Dwi Lestari

Department of English Teaching, Faculty of Teacher Training and Education

Universitas PGRI Madiun

Jalan Setiabudi No.85 Madiun

Email: intandwilestari82@gmail.com

\section{INTRODUCTION}

In the globalization era, English as one of the international languages is used by many people in many aspects of human life such as: scientific field, technology field, economic field, etc. According to Richard and Schmidt (2010: 196), "English as an international language is a term used to characterize the status of English as the worlds' major second language and the commonest language used for international business, trade, travel, communication, etc. It means that English has very important role as a communication 
means for both oral and written. The importance of using English is one of the ways to follow the development of globalization era.

In Indonesia, English is used as a foreign language. Learning a foreign language is an integrated process that learner should study the four basic skills. They are listening, speaking, reading, and writing skills. Writing is one of the basic skills which must be mastered by students in order to be able to communicate and socialize with the community. According to Richard and Schmidt (2010: 640), "Writing is viewed as the result of complex processes of planning, drafting, reviewing, and revising and some approaches to the teaching of first and second language writing teach students to use these processes. It means that writing is complex process and it can be complicated problem in creating the ideas, so it should be chose the appropriate technique to make decision as solve of problem in the process of writing.

One of writing texts that must be produced by the student is recount text. According to Knap and Watkins (2005:223), "Recounts are sequential texts that do little more than sequence a series of events". It means that recount is unfolding of a sequence of events overtime. The reason why the researcher discusses about recount because there are many text is only discuss about content without context of the text, so it must be pay attention by teacher to discuss genre text based on the content and context of the text

Furthermore, there are some problems faced by the teacher and students in teaching writing English. The English teachers do not use the appropriate technique in teaching writing, so it makes the students feel bored in writing. Then, students are generally confused by what they write, they usually get difficulties in building context or idea, and there are many errors in vocabulary, grammar, and spelling. Moreover, based on the result of observation during in-services teaching and learning, process of learning English in SMKN 1 Bendo as the subject in this research is still done conventionally. Process of learning is conducted by the teacher or teacher centered learning. Teacher centered learning is a system of learning where the knowledge is transmitted from the teacher to students, so the students passively receive information.

Here, the researcher uses Small Group Discussion as technique that helps the student to be active in learning. According to Slavin (2006: 234), "In a Small Group Discussion, students work in four to six member groups to discuss a particular topic". It means that Small Group Discussion is one of the techniques in learning which intend some students in small group to participate in a range of activities to develop students' thinking or complete practical task. By using this technique, the students are expected to be more open, active, and confident to express their ideas in learning process through discussion.

There are four stages in implementation of Small Group Discussion. Robertson in Anin Eka Sulistyawati (2012: 30) defines four stages in group discussion process. The first stage is the orientation stage which is used as the introduction the members in each group. They start to greet and introduce themselves to other members and make a vote on choosing the leader of their group. Next is the norm establishment stage, group members test one another and teacher. They will start discussing the topic with their members. While in the productive stage, group members focus both on the task and interpersonal relations. They have to decide which idea will be written as the best result. Debating some different idea may not happen in this stage any longer. And the last stage is the production stage, group members look back at their experience together and deal with the problems of parting.

\section{RESEARCH METHOD}

The researcher uses qualitative research as research approach and descriptive research as type of research. The researcher does this descriptive qualitative research in order to make description about the implementation, advantages and disadvantages, and solution of the disadvantages of Small Group Discussion in teaching writing Recount text.

The source of data in this research consists of three: social situation, participants, and documents. Social situation is place, actor, and activity which are used by the researcher to get the data. The sample of this research is students in the tenth grade in class GB1 of SMKN 1 Bendo which consist of 36 students. In

The implementation of small group discussion in teaching writing recount text... (Intan Dwi Lestari) 
this research, the researcher uses syllabus, lesson plan, name and score of the student, and photographs to know the implementation of Small Group Discussion in teaching writing Recount text.

The techniques of collecting data which are used by the researcher in this research are observation, interview and documentation. The researcher chooses nonparticipant observation as a type of the research observation. In collecting the data, the researcher uses direct observation especially participant observation. The researcher uses semi-structured interview as type of the interview. The researcher uses syllabus, lesson plan, name and score of the student, and photographs.

The researcher uses triangulation of the technique of validity data in this research. In this research, the researcher uses methodological triangulation as a form of triangulation in order to get the valid data. The researcher collects data from three sources. They are observation, interview, and documentation. The techniques of data analysis are used by the researcher in this research are data condensation which the researcher chooses and simplifies the data from observation, interview, and documentation, data display which the researcher displays the data which is taken from observation, interview, and documentation, then drawing and verifying conclusion which the researcher makes a summary from the research.

\section{RESULTS AND DISCUSSION}

There are three steps in the implementation of Small Group Discussion in teaching writing Recount text. They are presented as follows: Pre-Activities. First, the teacher greets the students by saying salam. The teacher says "good morning class, how are you today?" and the students give response by saying "good morning sir". The students show enthusiasm and ready to begin the lesson. Second, the teacher asks the students to pray together. Here, the teacher asks the leader of the class to guide to pray by saying "before we start the lesson, let's pray together please". Then, all of the students pray seriously. Third, the teacher checks the absent of the students by saying "who is absent today?" and the student give response by saying "complete sir". All of the students answer the question of the teacher with enthusiasm.

The last, the teacher explains the purpose of learning that is about the material in that meeting. The teacher states the purpose of learning that is about Recount text. The students give attention about the teachers' explanation. Whilst-Activities. There are four stages in implementation of Small Group Discussion. The first stage is the orientation stage. Robertson in Anin Eka Sulistyawati (2012: 30) states that "In this stage, group members find out about one another and their place in the group. They start to greet and introduce themselves to other members and make a vote on choosing the leader of their group". Here, the teacher initiates the treatment by dividing students into groups consisting of four students, so there were nine groups. Then, the teacher asks each group to define who would be the leader, secretary, other, and also explained their assignment based on their position. The students give response and show enthusiasm in dividing group, they make a vote to choose who are leader, secretary, and observer. Then, the teacher gives brainstorming by giving question about the types of the text. The process of dividing group runs well and it does not take much time because there is cooperation among them.

The second stage is the norm establishment stage. Robertson in Anin Eka Sulistyawati (2012: 30) states that "It is conducted where group members test one another and teacher. Test here means they will start discussing the topic with their members, even they might ask their teacher to give them some helps if it is needed. Conflict will naturally happen and this stage is as an opportunity to learn problem solving and interpersonal skill". Here, the teacher asks the students to identify the example of text, answer the questions about text, match the words, and answer fill in the blank questions with the appropriate verb in group. Actively, the student reads the text that the title is my day.

Then, they answer the questions of the text, match the words and answer the fill in the blank questions. They are enjoy when they answer the questions because they can discuss with their friends, then the process of answering the question does not take much time because the students can finish answer the questions quickly. After that, the teacher asks the student and the student give response to identify the use of

English Teaching Journal, Vol. 7, No. 1, June 2019: $20-27$ 
connective, modal, and tenses in the text. They are active in doing the identification the use of connective, modal, and tenses in the text.

During that processes, the teacher guides the students to get the meaning of difficult word and asks the difficulty of the students about the text. There are some of the students who ask to the teacher about the meaning of the word. There is curiosity of them to understand the text, so they can answer the questions carefully. The third stage is productive stage. Robertson in Anin Eka Sulistyawati (2012: 30) states that "This stage is generally the longest stage in the life of a group where group members focus both on the task and interpersonal relations. They have to decide which idea will be written as the best result. Debating some different idea may not happen in this stage any longer. Here, they focus on producing the answer in a paper". In this stage, the teacher asks the students to make a design or part of recount text based on the topic that have been given by the teacher. The teacher as facilitator in case difficulties of students.

The topic that discuss is popular, it is about holiday. They are active discuss what is the idea which will be written. The discussion is so attractive because the students have the different ideas, so debate happens about the argument related their idea about the topic,there are a lot of ideas which is showed by them because among of them have the experience of holiday, so they have to decide the idea first. The last stage is the termination stages. Robertson in Anin Eka Sulistyawati (2012: 30) states that "This is a stage where group members look back at their experience together and deal with the problems of parting. If they still have time, they can re-check their answers together, but they might not do it when the time is over". Here, the teacher asks the students to presents the result of recount text that has been written. Some of the students present the text, but there are students who do not present because the time is up. The teacher asks the students to give feedback, and. the students give feedback and ask question about the result of the other group actively. The students pay attention to the presentation and curious about the texts which have been written by their friend. Post-Activities

In this activity, the teacher and students review and make resume of the material. Before teacher give review and resume, teacher invites the student to give applause to their performance in the process of learning. The students are enthusiasm to give applause and they feel proud with the result of their work. Then, the teacher and the students review the material from the definition, generic structures, and language features of the text. All of the students joint in this process. It shows from their answer when the teacher guides to explain the material one more time. After that, the teacher asks students' difficulties during process of learning. There is student who says that the difficulty is about the meaning of the word, and it makes the student difficulty to write the text. Finally, the time is up. The teacher and students pray by reciting "Alhamdulillah" together. The teacher closes the meeting by reciting "see you later", and the students give response by reciting "see you later". All of the students pay attention what the teacher saying.

The advantages of the implementation of Small Group Discussion in teaching writing Recount text are as follows: It is easy to implement in the class and can be understood well by the students. It can be proved by the teacher's interview who says that the student can understand the text easily from the parts, generic structures, and language features of the text. It means that Small Group Discussion makes the students easy to understand the text. Moreover, based on the students' interview, one of students says that the activity of writing is easier because the parts of the text have been discussed and it is done in group. It means that Small Group Discussion helps the student in writing because the parts of the text have been discussed and the activities also do in group. In addition, Brewer (1997: 27) states that "it helps participant see relationship among ideas or concept related to the topic a hand". It means that the idea or concept related to the topic can understood by the student, so the purpose of learning can achieve through that activity. It is more effective to teach Recount text.

It can be proved by the teacher's interview who says that the technique is effective to teach writing because the activities are done in a group, so it helps and makes the student interest to write the text. It means that Small Group Discussion is technique of learning that make student interest to write the text, and also effective to teach Recount text. Moreover, based on the students' interview, one of students says that the

The implementation of small group discussion in teaching writing recount text... (Intan Dwi Lestari) 
activity is good because the structures of the text have been discussed when they answer the questions, so it makes the student understand the text easier. It means that Small Group Discussion is interesting technique that makes the student active in the process of learning through asking and giving questions, discussion, and presentation. In addition Brewer (1997: 27) states that "it is a good way to get participants interested in a topic". It means that Small Group Discussion is good way to get the interest of the student about the topic in order to get the activeness of the student in the process of learning. The situation of the class is more attractive because the students are more enthusiastic about teaching and learning activity

It can be proved by the teacher's interview who says that the situation of the class is more attractive, his opinion about the learning is the students are enthusiastic to follow the lesson. It means that the situation of the class is more attractive because students enthusiastic about teaching and learning activity. Moreover, based on the students' interview, one of students says that the activity is interesting. There are activities of asking and giving questions, discussion, and presentation, and the situation of the class is attractive and not bored. It means that the activity make the situation of the class is more attractive and not bored, and it makes the student enthusiastic in the process of learning. The activity is of course increase the students' participation. It can be proved by the teacher's interview who says that the activities increase the participation of the students. They are usually shy or do not talks can join to talk in that group discussion. It means that Small Group Discussion increase the participation of the student. They who shy to deliver their idea in front of the class, they can deliver in the discussion of their group. The student are active in the process of learning through asking and giving questions, presentation, or doing the task in group. It means that Small Group Discussion is technique of learning that makes the students active in the process of learning, and it is of course increase the participation of the students in the class.

Then, based on the students' interview, one of students says that the learning is enjoyable because they can join in the learning activity through asking and giving questions, discussion, and presentation in front of the class, so all of the students are active in the process of learning. It means that Small Group Discussion is a technique that can activate the student in participation through asking and giving questions, discussion, and presentation in front of the class, so the activity is of course the increased participation of the students. In addition Brewer (1997: 27) states that "All participants in the group can participate". It means that Small Group Discussion give opportunities for all of the participant in group to be active in the process of learning. It makes the students more intimate with their friend because they worked in group, so they will know each other. It can be proved by the teacher's interview who says that this technique is effective in teaching writing because the activities are done in group, the students can discuss with their friends, they can learn together, and it makes each of them know more about their self, so it helps them in the process of learning in the class. It means that Small Group Discussion is effective technique to teach writing because the activity is done in group, the student can discuss and learn with their friend, it makes the student know each other, and it is of course makes them more intimate in the process of learning.

Then, based on the students' interview, one of students says that the activity is good because the structure of the text is clear, it have been discussed when the students answer the questions. Then, because the activity is discussion, so they can more intimate with their friends. It means that Small Group Discussion is good technique because the structures of the text have been discussed, then because the activity is done in group, so student can more intimate with the other student. It makes the process of learning run well because it is supported by the good interaction between the students. The disadvantages of the implementation of Small Group Discussion in teaching writing Recount text are as follows: The students need more times to write the textbecause they are lack of vocabulary. It can be proved by the students' interview who one of them says that the time is so limit, so the writing is not maximal. It means that the student need more time to write the text in order to get the good result of writing. The students are difficult when they want to translate what they want to write in English. It can be proved by the students' interview who one of them says that there is difficulty of translate the meaning of the word, so the students need more time to write a text. It means that the student have difficulty in translate the word, so when they write the text take long time. There

English Teaching Journal, Vol. 7, No. 1, June 2019: $20-27$ 
is disability of implementing correct structure and the domination of the other students are the factor that makes them remains silent in the group, so some of the students do not participate to do the task.

It can be proved based on the teacher's interview who says that there are some of the students who are not active to participate in group discussion. It is because the factor of "shy" and the problem when they translate the word, so there is student who does not write the text. It means that there are some of the students who do not active to participate in the discussion, and it leads to a burden situation for them to write. Moreover, Brewer (1997: 27) states that "some participants in the group may do all the talking". It means that there are some participant do all the talking, they do not give the opportunities to the other student to speak, so it makes them remains silent in the group, they do not participate to do the task, and it leads to a burden situation for them to write. The students' motivation of writing out the language is still low.

It can be proved by the students' interview who one of them says that there is a problem that the students do not know the meaning because there is no dictionary, so they are not yet write the text until finish. It means that because of the student do not understand the meaning of the word, they are not yet finish their written text. Small Group Discussion takes long time in teaching and learning process. It can be proved based on the teacher's interview who says that in the implementation need long time because the students need more time to think what they want to write, the discussion is also need long time, and writing whole a text is of course need more time. It means that in implementation of Small Group Discussion take long time because the student need more time to think and discuss when they want to write the text fully. In addition Brewer (1997: 27) states that "It is time-consuming". It means that Small Group Discussion take much time in the implementation in the class.

The Solution of the Disadvantages in the Implementation of Small Group Discussion in Teaching Writing Recount Text for the Tenth Grade Students of SMKN 1 Bendo in Schooling Year of 2015/2016. The teacher gives the students clear and simple explanation about the material. It can be proved based on the teacher's interview who says that the explanation of the material is clear and simple, for example the students give the example of the text based on the situation around them or their experience. It means that the explanation of the teacher is clear and simple in order to make the students understand the text easily. The teacher explains the role of each member of group clearly so it makes students participate and do the job of them when they discuss in group.

It can be proved based on the teacher's interview who says that the dividing of the group is clear, so when the student do the task in group discussion becomes easy and directed. It means that the dividing of the role is clear, so when the student do task in group are easier and directed. Teacher asks the students to bring the dictionary to help them understand the vocabulary, grammar and meaning. It can be proved based on the teacher's interview who says that the teacher asks by the student to bring dictionary in English class, so when they get difficulty in translation the word, they can see the meaning in the dictionary. It means that the teacher asks their student to bring dictionary during the process of learning English. Moreover, based on the students' interview, one of students says that they bring the dictionary to translate the meaning of the word. It means that to find the meaning of the difficulties word, the student asked by teacher to bring dictionary. The teacher makes the activity of teaching and learning process in Small Group Discussion into simple one, so they can cover in one time or meeting.

It can be proved based on the teacher's interview who says that to implement the four stages of the technique is simpler, so it does not take long time, it can finish in one meeting. It means that the teacher makes the activity of teaching and learning process in Small Group Discussion into simple one, so it can be finished in one meeting. The teacher gives the student additional time because the processes of writing need long time. It can be proved based on the teacher's interview who says that because the process of writing is long, so the student gives the additional time to collect their work in the next day. It means that the long process of writing makes the teacher gives the additional time to collect students' work. Moreover, based on the students' interview, one of students says that the time is add because they need time to think what they want to write. It means that the student need more time because writing activity is long process and they need

The implementation of small group discussion in teaching writing recount text... (Intan Dwi Lestari) 
more time of think idea of their written text. The student aware to other student in order to make interaction with their friends.

It can be proved based on the teacher's interview who says that the interaction between the students run well because the student aware to other student. It means that the awareness between student is so important in order to make the interaction between them can run well, so it makes the student enjoy during the process of learning. The teacher gives the students a bit of joke or humor and motivation in the learning process. It can be proved based on the teacher's interview who says that when the teacher teaches the students, they are not only deliver the material but also they give motivation to the students during the process of learning, for example the teacher give humor in order to makes students are not too serious. It makes the situation of learning is relax and natural, so the students enjoy and understand the material easily. It means that the way of teachers' teach not only deliver the material, they also give motivation to the student, in order to get the purpose of the learning.

\section{CONCLUSION}

The implementation of Small Group Discussion in teaching writing Recount text has three steps. First is pre-activities, the teacher begins the class by greeting, praying, and checking attendance list. Second is whilst-activities which covers details explanation of four stages in group discussion process. The last is post-activities which recall the memory of the students about things that already done in the classroom. All of the activities are suitable with the lesson plan, observation, and teaching process in the class. After the researcher knows the real condition and situation, the researcher also gives the suggestion which might be useful for the teacher in conducting classroom activities, especially writing activities, they should have several references of teaching techniques. Then, the students are suggested to increase their vocabulary to make them successfully in learning writing. They are also should have high motivation and desire in improving their writing ability. The last, the other researcher are suggested do the next research and apply this technique in another writing class that related to this field.

\section{REFERENCES}

Barras, R. (2005). Students Must Write: A guide to better writing in coursework and examinations. New York: Routledge.

Berg, L. B. (2009). Qualitative Research Method for social sciences. United stated of America: A Person Education Company.

Boardman, C. A. (2008). Writing to communicate: Paragraph and Essays. Routledge: Pearson Longman.

Brewer, E. W. (1997). 13 Proven Ways to Get Your Message Across: The Essential Reference for Teachers, Trainers, Presenters, and Speakers. United States of America: Corwin Press Inc.

Brown, H. D. (2000). Principles of Language Learning and Teaching. San Fransisco: Addisison Longman Inc.

Edge, J. (1993). Essentials of English Language Teaching. New York: Longman.

Harmer, J. (2004). The Practice of English Teaching (3rd Edition). England: Longman.

Harmer, J. (2007). The Practice of English Language Teaching (Fourth Edition). England: person Education Limited.

Hastoyo, S. S. (2010). Improving Students' Speaking Competence through Small Group Discussion. Solo: Thesis-Unpublished.

Kamehameha Schools. (2007). The Writing Process: An Overview of Research on Teaching Writing as a Process. Hawai'i: Research \& Evaluation Departement of Kamehameha Schools.

English Teaching Journal, Vol. 7, No. 1, June 2019: 20-27 
Khotari, R.C. (2004). Research Methodology. New Delhi: New Age International.

Miles, M. B., Huberman, A. M., and Johnny, S. (2014). Qualitative Data Analysis. United States of America: Sage Publication.

Nasution, S. (2004). Metode Research. Jakarta: Bumi Aksara.

Nunan, D. (1991). Language teaching and methodology. Sidney: Prentice Hall

Peter, K \& Megan, W. (2005). Genre, Text, Grammar Technologies for Teaching and Assessing Writing. Australia: University of New South Wales Press Ltd.

Raimes, A. (1983). Technique in Teaching Writing. New York: Oxford University Press.

Reineke, M. J. Summary of Citing Internet Sites. In-Class Discussion, (Online) (http://www.uni.edu/reineke/guidelin.htm, accessed 8 June 2016, at 05.32 WIB).

Richards C, J. \& Schmidt, R. (2010). Longman Dictionary of Language Teaching and Applied Linguistics. Edinburg Gate: Pearson Education Limited.

Saragih, N., Silalahi, R., \& Pardede, H. (2014). The Effectiveness of Using Recount Text to Improve Writing Skill For Grade III Students of Kalam Kudus Elementary School 2 Pematangsiantar. IOSR Journal Of Humanities And Social Science (IOSR-JHSS) Volume 19, Issue 1, Ver. XII (Feb. 2014), PP 56-64.

Slavin, R. E. (2006). Educaitonal psychology: Theory and Practice. United States of America: Pearson Education Inc.

Sugiyono, S. (2014). Memahami Penelitian Kualitatif. Bandung: Alfabeta.

Sulistyawati, A. E. (2012). The use of cooperative learning in small group discussion in genre-based reading class. Thesis. Post Graduate Program Diponegoro University Semarang (Accessed on 25 March 2016 at 10.35 a.m.)

Ur, P. (1996). A course in Language Teaching: Practice and Theory. Cambridge: Cambridge University Press.

Wahyuni, S. (2015). Qualitative Research Method: Theory and Practice. Jakarta: Salemba Empat.

Yin, R. K. (2011). Qualitative Research from Start to Finish. New York: The Guildford Press. 